\title{
REFLEXÕES SOBRE O JULGAMENTO DA AÇÃO DIRETA DE INCONSTITUCIONALIDADE (ADI) N 5.766/DF E O ACESSO À JUSTIÇA DO TRABALHO NO BRASIL
}

\author{
Érica R. Guimarães Amorim* \\ Wilson Alves de Souza**
}

RESUMO: Este artigo se propõe a analisar criticamente o julgamento da Ação Direta de Inconstitucionalidade $\mathrm{n}^{\circ} 5.766 / \mathrm{DF}$ pelo Supremo Tribunal Federal, bem como, as repercussões que esta decisão irá proporcionar ao acesso à Justiça do Trabalho no Brasil. Somente o futuro poderá certificar, com precisão, quais as consequências da Reforma Trabalhista de 2017, entretanto, algumas projeções já foram traçadas neste breve ensaio.

Palavras-Chave: Ação Direta de Inconstitucionalidade no 5.766/DF; Acesso à Justiça; Reforma Trabalhista; Direitos Sociais; Processo do Trabalho.

\section{REFLECTIONS ON THE JUDGMENT OF THE DIRECT ACTION OF UNCONSTITUTIONALITY (ADI) No 5.766/DF AND THE ACCESS TO LABOR JUSTICE IN BRAZIL}

\begin{abstract}
This article proposes to critically analyze the judgment of the Direct Action of Unconstitutionality $n^{\circ} 5.766 / \mathrm{DF}$ by the Federal Supreme Court, as well as the repercussions that this decision will give access to Labor Justice in Brazil. Only the future can accurately certify the consequences of the 2017 Labor Reform, however, some projections have already been outlined in this article.
\end{abstract}

Keywords: Direct Action of Unconstitutionality $\mathrm{n}^{\circ}$ 5.766/DF; Access to justice; Labor Reform; Social Rights; Work Process.

\footnotetext{
${ }^{*}$ Mestranda em Direito pela Universidade Federal da Bahia (UFBA). Graduada pela mesma Instituição. Advogada.

${ }^{* *}$ Professor Titular (UFBA). Pós-doutor em Direito (Universidade de Coimbra). Doutor em Direito (UBA). Juiz Federal.
} 


\section{INTRODUÇÃO}

Depois da aprovação da Lei $n^{\circ} 13.467$ (BRASIL, 2017) surgiram muitas discussões acerca da constitucionalidade ou inconstitucionalidade de alguns dispositivos legais que sofreram alterações pela Reforma Trabalhista do governo de Michel Temer. Por essa razão, foram propostas no Supremo Tribunal Federal (STF) diversas Ações Diretas de Inconstitucionalidade que suscitam a inconstitucionalidade do aludido diploma legal.

Neste artigo, será estudada apenas ADI $n^{\circ} 5.766 / \mathrm{DF}$, tendo em vista sua relevância para o acesso à Justiça do Trabalho. Na citada ação constitucional houve a impugnação dos artigos 790-B caput e $\S 4^{\circ}, 791-\mathrm{A} \S 4^{\circ}$, e $844 \S^{\circ}$, do Decreto-Lei 5.452/43 (Consolidação das Leis Trabalhistas), com redação conferida pelo art. $1^{\circ}$ da Lei ${ }^{\circ} 13.467 / 17$, os quais tratam, em apertada síntese: sobre o pagamento dos honorários periciais e sucumbenciais pelo beneficiário da gratuidade de justiça, quando houver obtido em juízo, ainda que em outro processo, créditos capazes de suportar a referida despesa; bem como a condenação ao pagamento de custas ao beneficiário da justiça gratuita, o que pode ocorrer caso o reclamante tenha ensejado a extinção do processo, em face do não comparecimento à audiência, sendo que, nesta hipótese, o adimplemento das custas se torna condição para a propositura de nova demanda.

Noutras palavras, por meio da ADI $\mathrm{n}^{\circ}$ 5.766, busca-se a declaração de inconstitucionalidade dos supracitados artigos da Lei $\mathrm{n}^{\circ}$ 13.467/17, em decorrência de possível afronta aos princípios constitucionais da dignidade da pessoa humana, devido processo legal, inafastabilidade do controle jurisdicional, isonomia, assistência jurídica integral e gratuita aos necessitados, dentre outros, os quais serão apreciados nos tópicos a seguir.

O presente artigo é proveniente de uma investigação a uma demanda judicial do controle abstrato de constitucionalidade, qual seja: Ação Direta de Inconstitucionalidade $n^{\circ}$ 5.766/DF, porquanto o Supremo Tribunal Federal (STF) está prestes a decidir pela constitucionalidade ou não da imposição ao pagamento de custas e honorários (periciais e advocatícios) pelo beneficiário da gratuidade de justiça, desde que possuía créditos suficientes, ainda que em outro processo.

Assim, eis que surge o seguinte problema: quais as repercussões que o julgamento da ADI (n 5.766/DF) ocasionarão para a Justiça do Trabalho no Brasil? 
Cumpre frisar que também foram utilizados referenciais teóricos, de sorte que a pesquisa possui um viés qualitativo e natureza bibliográfica. Desse modo, o modelo teórico seguido foi o crítico-argumentativo, sistemático na organização das ideias centrais, sem, porém, se afastar das suas bases epistemológicas.

Há de se notar, por fim, que se elegeu o estudo descritivo e propositivo, com o intuito de debater as recentes alterações na legislação trabalhista, em especial os artigos 790-B caput e $\S 4^{\circ}, \S 4^{\circ}$ do $791-\mathrm{A}$ e $\S 2^{\circ}$ do 844 , todos da Lei $n^{\circ} 13.467 / 17$, como será demonstrado nas próximas linhas.

\section{CONTROLE ABSTRATO DE CONSTITUCIONALIDADE DE LEI E DEMAIS ATOS NORMATIVOS NO DIREITO BRASILEIRO}

Inicialmente, importa esclarecer que a Ação Direta de Inconstitucionalidade (ADI) surgiu no ordenamento jurídico pátrio com a Constituição de 1934, “(...), porém, foi com a Emenda Constitucional $n^{\circ}$ 16/1965 que de fato o Brasil adotou esse modelo ao lado do sistema americano, controlando abstratamente as leis e atos normativos federais e estaduais frente à Constituição Federal” (CUNHA JÚNIOR: 2016, p. 183).

A Magna Carta de 1988 ampliou e aperfeiçoou o sistema, criando novas ações diretas e estendendo a legitimidade para a propositura da demanda a outras autoridades, órgãos e entidades. Assim, foi instaurada no ordenamento pátrio uma fiscalização abstrata das leis e atos normativos do poder público, incumbindo ao Supremo Tribunal Federal (STF) processar e julgar as ações do controle concentrado de constitucionalidade (CUNHA JÚNIOR: 2016, p. 183).

Há de se perceber que tais mecanismos de fiscalização da fidelidade das normas infraconstitucionais à constituição se fundamentam na supremacia e rigidez das normas constitucionais (DIDIER Jr.: 2013, p. 406 e 407).

Noutras palavras, a noção de inconstitucionalidade decorre diretamente do princípio da hierarquia das normas jurídicas, segundo o qual as normas inferiores extraem a sua validade das normas superiores. A constituição está acima de todas as demais normas de um ordenamento jurídico, sendo inconstitucional qualquer outra manifestação normativa que lhe contrarie diretamente.

Nota-se que no controle concentrado o objeto principal da ação é a própria questão constitucional, no que difere do controle difuso, cuja discussão sobre a constitucionalidade ou 
inconstitucionalidade de uma lei ou ato do poder público se apresenta como questão prejudicial ao conflito intersubjetivo travado entre as partes do processo (CUNHA JÚNIOR: 2016, p. 184).

Vale frisar que as ações constitucionais diretas têm natureza dúplice, o que significa dizer que em caso de improcedência a demanda, e não acolhido o pedido de declaração de inconstitucionalidade ou constitucionalidade, o STF deverá declarar a constitucionalidade ou a inconstitucionalidade do ato normativo questionado (CUNHA JÚNIOR: 2016, p. 195).

Em 1999, foi editada a Lei $\mathrm{n}^{\circ}$ 9.868, responsável por disciplinar o processo e julgamento da ADI (Ação Declaratória de Inconstitucionalidade), assim como da ADC (Ação Declaratória de Constitucionalidade). Nos tópicos a seguir, serão analisados os pormenores da ADI $n^{\circ}$ 5.766/DF, a fim de se ter um aprofundamento acerca dessa relevante ação constitucional.

\section{A ADI N 5.766/DF E SEUS FUNDAMENTOS}

Com a edição da Lei n ${ }^{\circ} 13.467$ (BRASIL, 2017), então denominada de "Reforma Trabalhista", diversos dispositivos da Consolidação das Leis Trabalhistas (CLT) foram alterados, sem sequer propiciar o devido debate acerca da razoabilidade e proporcionalidade das modificações realizadas.

Em decorrência da agilidade para a aprovação de tal Lei, a mesma está sendo alvo de diversas impugnações, a exemplo das Ações Diretas de Inconstitucionalidade $\mathrm{n}^{\circ} 5.794$ (impugna as alterações sobre contribuição sindical obrigatória), $\mathrm{n}^{\circ} 5.806$ (discorre acerca do trabalho intermitente), $\mathrm{n}^{\circ} 5.870$ (questiona os limites a indenizações por danos morais) (STF, 2018, on line).

$\mathrm{Na}$ ADI $n^{\circ}$ 5.766/DF, com pedido de medida cautelar, proposta pela ProcuradoriaGeral da República, assinada pelo então Procurador-Geral Rodrigo Janot M. de Barros em 25/08/17, e admitida pelo STF para ser apreciada e julgada pelo plenário da Corte (STF, 2018, on line), sustentou-se e se pediu, em resumo, que:

a) os artigos 790-B caput e $\$ 4^{\text {o1 }}$ e $791-\mathrm{A} \$ 4^{\circ 2}$, da CLT (alterada pela Lei $\mathrm{n}^{\circ}$ 13.467/17), estão eivados de inconstitucionalidade material, uma vez que impõem ao

\footnotetext{
${ }^{1}$ Art. 790-B. A responsabilidade pelo pagamento dos honorários periciais é da parte sucumbente na pretensão objeto da perícia, ainda que beneficiária da justiça gratuita.
} 
beneficiário da gratuidade de justiça a obrigação de arcar com os honorários periciais e advocatícios, desde que possuam créditos capazes de suportá-los, sendo que o Código de Processo Civil (CPC) não traz essa previsão legal. Pelo contrário, o CPC dispõe expressamente que a justiça gratuita abrange as custas, despesas processuais e honorários sucumbenciais $^{3}$; há de se esclarecer, por oportuno, que o CPC/2015 revogou, em parte, a Lei $\mathrm{n}^{\mathrm{o}}$ 1.060/50, contudo, as disposições acerca da gratuidade de justiça continuam vigentes, por meio dos artigos 98 a 102 da Lei $n^{\circ} 13.105 / 15$;

b) a redação anterior do caput do artigo $790-\mathrm{B}^{4}$ dispunha que caberia ao sucumbente da reclamação trabalhista arcar com os honorários periciais, exceto se houvesse a concessão do benefício da gratuidade de justiça; apesar disso, a nova redação do $\S^{\circ}$, do art. 790-B, prevê que, uma vez existindo créditos capazes de custear os honorários, compete ao beneficiário da justiça gratuita pagá-los, ainda que tais créditos sejam provenientes de outros processos; resta fulgente que no novo dispositivo não se atentou para o fato de que eventuais

[...]

$\S 4^{\circ}$ Somente no caso em que o beneficiário da justiça gratuita não tenha obtido em juízo créditos capazes de suportar a despesa referida no caput, ainda que em outro processo, a União responderá pelo encargo." (NR)

${ }^{2}$ Art. 791-A. Ao advogado, ainda que atue em causa própria, serão devidos honorários de sucumbência, fixados entre o mínimo de $5 \%$ (cinco por cento) e o máximo de $15 \%$ (quinze por cento) sobre o valor que resultar da liquidação da sentença, do proveito econômico obtido ou, não sendo possível mensurá-lo, sobre o valor atualizado da causa.

$[\ldots]$

$\S 4^{\circ}$ Vencido o beneficiário da justiça gratuita, desde que não tenha obtido em juízo, ainda que em outro processo, créditos capazes de suportar a despesa, as obrigações decorrentes de sua sucumbência ficarão sob condição suspensiva de exigibilidade e somente poderão ser executadas se, nos dois anos subsequentes ao trânsito em julgado da decisão que as certificou, o credor demonstrar que deixou de existir a situação de insuficiência de recursos que justificou a concessão de gratuidade, extinguindo-se, passado esse prazo, tais obrigações do beneficiário.

${ }^{3}$ Art. 98. A pessoa natural ou jurídica, brasileira ou estrangeira, com insuficiência de recursos para pagar as custas, as despesas processuais e os honorários advocatícios tem direito à gratuidade da justiça, na forma da lei.

$\S 1^{\circ}$ A gratuidade da justiça compreende:

I - as taxas ou as custas judiciais;

II - os selos postais;

III - as despesas com publicação na imprensa oficial, dispensando-se a publicação em outros meios;

IV - a indenização devida à testemunha que, quando empregada, receberá do empregador salário integral, como se em serviço estivesse;

V - as despesas com a realização de exame de código genético - DNA e de outros exames considerados essenciais;

VI - os honorários do advogado e do perito e a remuneração do intérprete ou do tradutor nomeado para apresentação de versão em português de documento redigido em língua estrangeira;

VII - o custo com a elaboração de memória de cálculo, quando exigida para instauração da execução;

VIII - os depósitos previstos em lei para interposição de recurso, para propositura de ação e para a prática de outros atos processuais inerentes ao exercício da ampla defesa e do contraditório;

IX - os emolumentos devidos a notários ou registradores em decorrência da prática de registro, averbação ou qualquer outro ato notarial necessário à efetivação de decisão judicial ou à continuidade de processo judicial no qual o benefício tenha sido concedido.

${ }^{4}$ Art. 790-B. A responsabilidade pelo pagamento dos honorários periciais é da parte sucumbente na pretensão objeto da perícia, salvo se beneficiária de justiça gratuita. (Incluído pela Lei n. 10.537/02).

Rev. de Direitos Fundamentais nas Relações do Trabalho, Sociais e Empresariais | e-ISSN: 2525-9903 | Porto Alegre | v. 4 |

n. 2 | p. 106-126 | Jul/Dez. 2018 
créditos obtidos em litígios, em regra, não retiram a qualidade de hipossuficiência da pessoa; da maneira que foi redigida a nova legislação, verbas de caráter alimentar concedidas em processos judiciais ou mesmo administrativos (pois a Lei não esclarece a abrangência da norma) podem ser utilizadas para o custeamento dos honorários, retirando do trabalhador recursos essenciais para sua sobrevivência e de sua família, em total afronta à Constituição;

c) o novel art. 791-A, $\S 4^{\circ}$, da CLT, é uma das maiores inovações implementadas pela Reforma Trabalhista de 2017, já que não existia tal previsão legal; "por muito tempo a jurisprudência trabalhista entendeu-os indevidos, em face da capacidade postulatória das partes (CLT, art. 791), salvo na hipótese de assistência judiciária gratuita prestada por sindicato da categoria profissional” (STF, 2018, on line); em 2016, o Tribunal Superior do Trabalho (TST) alterou a súmula $\mathrm{n}^{\mathrm{o}} 219$, admitindo o pagamento de honorários advocatícios também nos casos em que o sindicato da categoria atue como substituto processual em ações rescisórias e nas demandas não provenientes da relação empregatícia (Resolução n. 204/2016, do TST); mas somente com a aprovação da Lei $n^{0} 13.467 / 17$ é que a incidência dos honorários advocatícios passou a vigorar para todas as ações trabalhistas, até mesmo nas causas em que ocorre sucumbência recíproca ${ }^{5}$;

d) semelhantemente ao $\S 4^{\circ}$ do art. 790-B, o $\S 4^{\circ}$ do art. 791-A, também impõe ao beneficiário da gratuidade de justiça o pagamento dos honorários advocatícios sucumbenciais, desde que tenha adquirido, mesmo que em outro processo, créditos suficientes para custear a aludida despesa; caso não seja constatada a existência de recursos financeiros (ainda que em outros processos) a obrigação ficará sob condição suspensiva de exigibilidade, pelo prazo de dois anos subsequentes ao trânsito em julgado da decisão que a certificou, competindo à parte adversa demonstrar, dentro do prazo, que cessou a condição de hipossuficiência financeira do beneficiário da gratuidade; depois do transcurso de dois anos, a obrigação será totalmente extinta;

e) além das inconstitucionalidades verificadas nos artigos 790-B caput e $\$ 4^{\circ}$ e 791-A $\S 4^{\circ}$ da Lei $n^{\circ} 13.467 / 17$, há flagrante inconstitucionalidade do novo $\S 2^{\circ}$ do art. 844 da

\footnotetext{
${ }^{5}$ Art. 791-A. Ao advogado, ainda que atue em causa própria, serão devidos honorários de sucumbência, fixados entre o mínimo de 5\% (cinco por cento) e o máximo de 15\% (quinze por cento) sobre o valor que resultar da liquidação da sentença, do proveito econômico obtido ou, não sendo possível mensurá-lo, sobre o valor atualizado da causa.

$\S 3^{\circ} \mathrm{Na}$ hipótese de procedência parcial, o juízo arbitrará honorários de sucumbência recíproca, vedada a compensação entre os honorários.
} 
$\mathrm{CLT}^{6}$, em que se onera o reclamante ausente a audiência, condenando-o ao pagamento das custas processuais (nos termos do art. 789, da CLT), mesmo tendo o autor obtido o benefício da gratuidade de justiça; essa obrigação somente não será exigível se o trabalhador comprovar, no prazo de 15 (quinze dias), que o não comparecimento ocorreu por motivo legalmente justificável, entretanto, inexiste consenso doutrinário e jurisprudencial sobre o que possa ser classificado como "motivo legalmente justificável”; como se não bastasse, o $\$ 3^{\circ}$ do dispositivo em comento, ainda afirma que o adimplemento das custas processuais é condição de admissibilidade de nova demanda, sobrepondo o interesse da União (recebimento das custas) à vontade da Carta de 1988 (art. $5^{\circ}$, incisos XXXV e LXXIV);

f) os dispositivos acima elencados padecem de inconstitucionalidade material, na medida em que violam diretamente os princípios constitucionais da dignidade da pessoa humana (art. $1^{\circ}$, III, da CF), dos valores sociais do trabalho e da livre iniciativa ${ }^{7}$ (art. $1^{\circ}, \mathrm{IV}$ ), da isonomia ${ }^{8}$ (art. $3^{\circ}$, I e III), da inafastabilidade de jurisdição, do devido processo legal e da assistência jurídica integral e gratuita aos necessitados (art. $5^{\circ}$, incisos XXXV, LIV e LXXIV, respectivamente) $)^{9}$; “em face da intensidade dos obstáculos econômicos impostos aos direitos

\footnotetext{
${ }^{6}$ Art. 844 - O não-comparecimento do reclamante à audiência importa o arquivamento da reclamação, e o nãocomparecimento do reclamado importa revelia, além de confissão quanto à matéria de fato.

[...]

$\S 2^{\circ} \mathrm{Na}$ hipótese de ausência do reclamante, este será condenado ao pagamento das custas calculadas na forma do art. 789 desta Consolidação, ainda que beneficiário da justiça gratuita, salvo se comprovar, no prazo de quinze dias, que a ausência ocorreu por motivo legalmente justificável. (Incluído pela Lei no 13.467 , de 2017).

$\S 3^{\circ} \mathrm{O}$ pagamento das custas a que se refere o $\S 2^{\circ}$ é condição para a propositura de nova demanda. (Incluído pela Lei $\mathrm{n}^{\circ} 13.467$, de 2017).

${ }^{7}$ Art. $1^{\circ}$ A República Federativa do Brasil, formada pela união indissolúvel dos Estados e Municípios e do Distrito Federal, constitui-se em Estado Democrático de Direito e tem como fundamentos:

[...]

III - a dignidade da pessoa humana;

IV - os valores sociais do trabalho e da livre iniciativa;

${ }^{8}$ Art. $5^{\circ}$ Todos são iguais perante a lei, sem distinção de qualquer natureza, garantindo-se aos brasileiros e aos estrangeiros residentes no País a inviolabilidade do direito à vida, à liberdade, à igualdade, à segurança e à propriedade, nos termos seguintes:

Art. $3^{\circ}$ Constituem objetivos fundamentais da República Federativa do Brasil:

I - construir uma sociedade livre, justa e solidária;

[...]

III - erradicar a pobreza e a marginalização e reduzir as desigualdades sociais e regionais;

${ }^{9}$ Art. $5^{\circ}$ Todos são iguais perante a lei, sem distinção de qualquer natureza, garantindo-se aos brasileiros e aos estrangeiros residentes no País a inviolabilidade do direito à vida, à liberdade, à igualdade, à segurança e à propriedade, nos termos seguintes:

XXXVI - a lei não prejudicará o direito adquirido, o ato jurídico perfeito e a coisa julgada;

$[\ldots]$

LIV - ninguém será privado da liberdade ou de seus bens sem o devido processo legal;

$[\ldots]$

LXXIV - o Estado prestará assistência jurídica integral e gratuita aos que comprovarem insuficiência de recursos;
}

Rev. de Direitos Fundamentais nas Relações do Trabalho, Sociais e Empresariais | e-ISSN: 2525-9903 | Porto Alegre | v. 4 |

n. 2 | p. $106-126$ | Jul/Dez. 2018 
fundamentais dos demandantes pobres, as normas impugnadas ainda incorrem em inconstitucionalidade por violação aos princípios da proporcionalidade e da proibição de excesso, configurando desvio de finalidade legislativa" (STF, 2018, on line);

g) a Constituição prescreve $\left(\$ 2^{\circ}\right.$ do art. $\left.5^{\circ}\right)$ que os direitos e garantias nela explicitados não excluem outros fixados em normas internacionais, como os editados pela Organização Internacional do Trabalho (OIT) - órgão integrante da Organização das Nações Unidas (ONU) - responsável por regular normas internacionais sobre direito do trabalho;

h) seja declarada a inconstitucionalidade material do artigo $1^{\circ}$ da Lei $\mathrm{n}^{\circ}$ 13.467/17, nos pontos em que altera ou insere disposições na CLT, especificamente os artigos: 790-B caput e $\S 4^{\circ}, \S^{\circ}$ do $791-\mathrm{A}$ e $\S 2^{\circ}$ do art. 844, do Decreto-lei ${ }^{\circ}$ 5.452/43 (STF, 2018, on line).

Até o presente momento, o pedido cautelar ainda não foi apreciado, uma vez que o Ministro Relator, Luís Roberto Barroso, determinou a oitiva da Câmara dos Deputados, do Senado Federal e do Presidente da República e da Advocacia-Geral da União.

\section{FUNDAMENTOS DOS DEFENSORES DA LEI QUESTIONADA}

Em linhas gerais, o processo legislativo para aprovação de qualquer projeto de lei precisa, necessariamente, de pronunciamento favorável da Câmara dos Deputados e do Senado Federal, bem assim a sanção do Presidente da República. Por isso mesmo, tais órgãos devem ser cientificados nesse tipo de processo para a defesa da lei que editaram. Ademais, é necessária a ciência da Advocacia-Geral da União para o mesmo fim.

\subsection{Da Câmara dos Deputados}

Intimada a se manifestar, a Câmara dos Deputados Federais apresentou petição na ADI $n^{\circ} 5.766 / \mathrm{DF}$, defendendo que inexiste qualquer inconstitucionalidade formal ou material na Lei ${ }^{\circ}$ 13.467/17, já que o mencionado diploma legal cumpriu todo o processo legislativo, sendo, inclusive, aprovado na Comissão de Constituição, Justiça e Cidadania (órgão responsável por apreciar a conformidade dos projetos de lei com a Constituição).

No que tange ao processo formal da referida Lei, sustentou-se que foram realizadas diversas audiências públicas e ouvidos representantes da sociedade civil, bem como, juristas 
especialistas nos temas a serem modificados pela Reforma Trabalhista, "além de terem sido realizados diversos fóruns estaduais, tudo com o intuito de incluir uma maior parcela da sociedade nos debates da matéria" (STF, 2018, on line).

Em relação ao conteúdo dos artigos impugnados na ação direta, a Câmara de Deputados se posicionou no sentido de que a concessão irrestrita do benefício da gratuidade de justiça criou um ambiente favorável ao ajuizamento de demandas temerárias, desprovidas de base jurídica e de má-fé, porquanto "a ausência de ônus ao litigante de má-fé estimula a apresentação de lides infundadas, em que o reclamante se aventura no Judiciário quase que para 'tentar tirar a sorte' às custas do reclamado" (STF, 2018, on line); assim, ao invés de proteger as garantias dadas aos trabalhadores, tinha-se o cerceamento do direito a uma justiça eficaz, tendo em vista o Relatório Geral da Justiça do Trabalho, que demonstra o déficit na arrecadação de custas, que, ao seu passo, impacta no funcionamento da máquina estatal (STF, 2018, on line).

Aduziu a Câmara dos Deputados que o regime anterior incentivava o oportunismo, na medida em que retirava do beneficiário da gratuidade de justiça os riscos naturais do processo (custas processuais, ônus de sucumbência, honorários periciais e advocatícios). A Reforma Trabalhista trouxe uma nova feição à Justiça do Trabalho, de modo que se o beneficiário da gratuidade de justiça passa a dispor de recursos financeiros - decorrentes daquele ou de outro processo - deve arcar com as custas e honorários, "sob o risco de estar enriquecendo-se ilicitamente às custas do Estado" (STF, 2018, on line).

No que se refere ao pleito cautelar, a Câmara dos Deputados afirmou que não restaram comprovados os requisitos autorizadores para concessão de tal medida, isso porque inexiste óbice ao acesso à justiça; "ao contrário, a nova normatização visa a efetividade judicial, diante do desestímulo de condutas potencialmente abusivas e lesivas ao Estado" (STF, 2018, on line).

Acrescentou o referido órgão do Congresso Nacional que o reclamante sucumbente somente terá que arcar com as custas e honorários processuais se tiver créditos - naquele ou em outro processo - a receber, no âmbito das demandas processadas na Justiça do Trabalho (STF, 2018, on line).

\subsection{Do Senado Federal}

Rev. de Direitos Fundamentais nas Relações do Trabalho, Sociais e Empresariais | e-ISSN: 2525-9903 | Porto Alegre | v. 4 | n. 2 | p. $106-126$ | Jul/Dez. 2018 
A Advocacia do Senado Federal também apresentou sua peça de defesa, argumentando que foi necessária a modernização da legislação trabalhista, porquanto a redação anterior da CLT eximia o beneficiário da gratuidade de justiça de qualquer responsabilidade natural da sucumbência de uma demanda judicial (STF, 2018, on line).

No caso do art. 790-B caput e $\S 4^{\circ}$, previu-se a possibilidade de responsabilização pelos honorários periciais do beneficiário sucumbente, desde que advenham créditos (do mesmo processo ou de outro litígio) que possam suportar tal despesa. Sustentou-se, assim, que a legislação reformista trouxe regras mais coerentes para a coletividade, na medida em que inexiste justiça gratuita, pois alguém sempre terá que pagá-la. Esse alguém é a sociedade que, por meio dos tributos estatais, arca com a manutenção do aparato judicial. "Desse modo, ainda que o empregado a quem se deferira justiça gratuita ganhasse uma fortuna na ação trabalhista em questão ou em outro processo, a União, ou seja - a sociedade - teria que arcar com os custos da perícia" (STF, 2018, on line).

Para o Senado Federal, criou-se o art. 791-A e seus parágrafos, no intuito de conter demandas frívolas e mal-intencionadas, destarte, os honorários advocatícios sucumbenciais passaram a ser previstos expressamente na CLT. No que se refere ao $\S 4^{\circ}$, do citado dispositivo, não se vislumbra qualquer inconstitucionalidade, notadamente porque somente será imputado ao beneficiário da gratuidade de justiça a obrigação de custear os honorários advocatícios caso o mesmo obtenha capacidade de pagamento para tanto; se isso não ocorrer, a aludida obrigação ficará sob condição suspensiva de exigibilidade por dois anos subsequentes ao trânsito em julgado da decisão, sendo totalmente extinta a obrigação após o transcurso de tal prazo, o qual é três anos menor do que aquele previsto no $\S 3^{\circ}$, do art. 98 , do Código de Processo Civil ${ }^{10}$.

Além disso, expôs que é plenamente constitucional o $\S 2^{\circ}$ do art. 844, da CLT, tendo em vista que a nova regra estabelece o prazo de 15 (quinze) dias para que o trabalhador possa justificar o não comparecimento à audiência. Portanto, na visão do Senado Federal, “inconstitucional seria permitir que a parte que mobilizou recursos e pessoal públicos e

\footnotetext{
${ }^{10}$ Art. 98. A pessoa natural ou jurídica, brasileira ou estrangeira, com insuficiência de recursos para pagar as custas, as despesas processuais e os honorários advocatícios tem direito à gratuidade da justiça, na forma da lei. [...]

$\S 3^{\circ}$ Vencido o beneficiário, as obrigações decorrentes de sua sucumbência ficarão sob condição suspensiva de exigibilidade e somente poderão ser executadas se, nos 5 (cinco) anos subsequentes ao trânsito em julgado da decisão que as certificou, o credor demonstrar que deixou de existir a situação de insuficiência de recursos que justificou a concessão de gratuidade, extinguindo-se, passado esse prazo, tais obrigações do beneficiário.
} 
privados para instaurar o processo simplesmente se omita sem qualquer motivação" (STF, 2018, on line).

Por fim, alegou o Senado Federal que os recursos públicos são escassos, de sorte que sua alocação precisa ser feita de modo eficiente e racional, proporcionando a universalização de direitos básicos. Por tais razões, sustentou que descabe o pleito cautelar formulado pela parte requerente, pois, no caso em apreço, inexistem o fumus boni juris (fumaça do bom direito) e o periculum in mora (perigo da demora).

\subsection{Da Advocacia-Geral da União}

Compete a Advocacia Geral da União (AGU), nos termos do $\S 3^{\circ}$ do art. 103, da $\mathrm{CF}^{11}$, defender lei ou ato normativo federal impugnado em ação direta de inconstitucionalidade, representando os interesses da Presidência da República em todo o processo.

No caso em estudo, a AGU apresentou defesa argumentando que a nova legislação trabalhista aproveitou as virtudes da Lei $\mathrm{n}^{\mathrm{o}}$ 1.060/50, contudo, trouxe a análise da situação financeira do reclamante até o término da demanda judicial. "O tratamento assistencial será concedido na forma de 'dispensa de antecipação', cujos benefícios serão circunstanciados à permanência da situação de carência financeira durante o curso do processo" (STF, 2018, on line).

Dessa forma - continuou -, evita-se o desperdício de recursos públicos, uma vez que aqueles que obtiveram capacidade de pagamento, durante o transcurso do processo, para arcar com as custas e honorários deverão quitá-los. "Afinal, os benefícios distribuídos alteram a percepção de risco dos potenciais demandantes em relação à propositura de ações, criando incentivos não raro criticáveis à judicialização" (STF, 2018, on line).

Afirmou, ainda, a AGU que a legislação reformista facilitou a prova da insuficiência de recursos, isso porque antes o benefício apenas era concedido às pessoas que percebessem remuneração igual ou inferior ao dobro do salário mínimo legal, e após a reforma trabalhista

\footnotetext{
${ }^{11}$ Art. 103. Podem propor a ação direta de inconstitucionalidade e a ação declaratória de constitucionalidade: (Redação dada pela Emenda Constitucional nº 45, de 2004).

$[\ldots]$

$\S 3^{\circ}$ Quando o Supremo Tribunal Federal apreciar a inconstitucionalidade, em tese, de norma legal ou ato normativo, citará, previamente, o Advogado-Geral da União, que defenderá o ato ou texto impugnado.
} 
quem recebe até $40 \%$ (quarenta por cento) do limite máximo dos benefícios do Regime Geral da Previdência Social (RGPS) tem direito à gratuidade de justiça ${ }^{12}$.

Ademais, sustentou a AGU que inexiste ofensa ao princípio da proporcionalidade ou sequer desvio de finalidade legislativa - como acusado na peça inaugural -, tendo em vista que as alterações realizadas foram necessárias e não constrangem o acesso à Justiça do Trabalho. "A narrativa civilizatória dos direitos fundamentais não deve servir à perpetuação de padrões de assistência social perdulários, ineficientes, que induzem à dependência do Estado" (STF, 2018, on line).

Concluiu, assim, a AGU que o sistema de concessão da justiça gratuita, adotado antes da reforma, estimulava demandas frívolas, porquanto havia uma impossibilidade prática de fiscalização; por outro lado, as novas regras apresentadas pela Lei $n^{\circ} 13.467 / 17$ trazem critérios racionais e eficientes; incabível se torna, destarte, a concessão da medida cautelar por ausência dos requisitos autorizadores, bem como, deve ser rechaçada a ADI $\mathrm{n}^{\circ}$ 5.766, notadamente por existir conformação dos dispositivos atacados à Constituição Republicana (STF, 2018, on line).

\section{INTERVENÇÕES DE AMICUS CURIAE}

Imperioso elucidar que o legislador permitiu a intervenção do "amicus curiae" (amigo da Corte) no controle abstrato de constitucionalidade ${ }^{13}$. Trata-se de um terceiro especial ou colaborador informal que pode intervir no feito, desde que demonstre um interesse objetivo na questão jurídico-constitucional em discussão, possua pertinência temática a atividade por si desenvolvida e represente eficazmente determinado setor da sociedade. $\mathrm{O}$ “amicus curiae" possibilita a pluralização do debate, conferindo maior legitimidade à decisão

\footnotetext{
${ }^{12}$ Art. 790. Nas Varas do Trabalho, nos Juízos de Direito, nos Tribunais e no Tribunal Superior do Trabalho, a forma de pagamento das custas e emolumentos obedecerá às instruções que serão expedidas pelo Tribunal Superior do Trabalho. (Redação dada pela Lei no 10.537 , de 27.8.2002).

$[\ldots]$

$\S 3^{\circ}$ É facultado aos juízes, órgãos julgadores e presidentes dos tribunais do trabalho de qualquer instância conceder, a requerimento ou de ofício, o benefício da justiça gratuita, inclusive quanto a traslados e instrumentos, àqueles que perceberem salário igual ou inferior a $40 \%$ (quarenta por cento) do limite máximo dos benefícios do Regime Geral de Previdência Social. (Redação dada pela Lei no 13.467 , de 2017).

${ }^{13}$ Art. $7^{\circ}$ Não se admitirá intervenção de terceiros no processo de ação direta de inconstitucionalidade.

$\S 1^{\circ}$ (VETADO)

$\S 2^{\circ} \mathrm{O}$ relator, considerando a relevância da matéria e a representatividade dos postulantes, poderá, por despacho irrecorrível, admitir, observado o prazo fixado no parágrafo anterior, a manifestação de outros órgãos ou entidades.
}

Rev. de Direitos Fundamentais nas Relações do Trabalho, Sociais e Empresariais | e-ISSN: 2525-9903 | Porto Alegre | v. 4 |

n. 2 | p. $106-126$ | Jul/Dez. 2018 
da Suprema Corte (CUNHA JÚNIOR: 2016, p. 202).

Destarte, há de se reconhecer a importância da figura do "amicus curiae" não somente na ação direta ora em estudo, mas em todas as formas de controle de constitucionalidade (concentrado ou difuso), obviamente por ser um avanço na democratização do sistema de jurisdição constitucional.

$\mathrm{Na}$ ADI $n^{\circ} 5.766 / \mathrm{DF}$, diversas instituições requereram a participação no processo como amicus curiae, entretanto, tal direito apenas fora deferido para "Central Única dos Trabalhadores - CUT”, "Central Geral dos Trabalhadores do Brasil - CTGB”, "Central dos Sindicatos Brasileiros - CSB”, “Associação Nacional dos Magistrados da Justiça do Trabalho - ANAMATRA", "Confederação Nacional do Transporte - CNT" e "Confederação da Agricultura e Pecuária no Brasil - CNA” (STF, 2018, on line).

Cada uma dessas instituições apresentou manifestação nos autos do processo, obtendo ainda o direito de serem ouvidas na sessão de julgamento da ADI no 5.766 no STF, iniciada em 09 de maio de 2018.

\section{OS VOTOS ATÉ AGORA PROFERIDOS}

Cumpre esclarecer que o conceito de constitucionalidade ou inconstitucionalidade é relacional, na medida em que depende da interação do comportamento estatal com a Constituição. Noutras palavras, significa que os atos do poder público podem expressar conformidade ou desconformidade com as regras e princípios constitucionais. Assim expõe Dirley da Cunha Júnior (2016, p. 184): “A relação de desconformidade entre a Constituição e o comportamento estatal, todavia, há de ser necessariamente direta, que se traduza exatamente numa violação direta e imediata de uma norma constitucional”.

Esse comportamento pode ser uma ação ou omissão do Estado, mas sempre deve constituir uma violação direta e imediata ao sistema formal ou às regras e princípios constitucionais (CUNHA JÚNIOR: 2016, p. 185). Adverte-se que somente as constituições rígidas ensejam o fenômeno jurídico da inconstitucionalidade, em decorrência da sua supremacia no ordenamento jurídico.

Até o momento, foram proferidos apenas os votos dos Ministros Luís Roberto Barroso (Relator do processo) e Edson Fachin, ficando o julgamento suspenso por conta do pedido de vista do Ministro Luiz Fux. Segue-se a exposição dos votos proferidos. 


\subsection{Do Ministro Relator, Luís Roberto Barroso}

Expôs o Ministro Roberto Barroso, Relator do processo, que se trata de um tema suscetível a ideologias, por isso, iniciou esclarecendo suas pré-compreensões acerca desta problemática, afirmando que existem três causas principais para o excesso de processos na Justiça do Trabalho: $\left(1^{\circ}\right)$ o fato dos empregadores não adimplirem devidamente com as verbas trabalhistas, $\left(2^{\circ}\right)$ amplo ajuizamento de demandas temerárias e oportunistas, $\left(3^{\circ}\right)$ legislação complexa e de difícil cumprimento para os empregadores. "Proteção fora da justa medida desprotege", afirmou o Ministro (STF, 2018, on line).

O Relator declarou que o volume exponencial de ações na Justiça do Trabalho tem prejudicado o andamento dos processos, já que os Tribunais Trabalhistas não têm conseguido fornecer uma prestação jurisdicional em tempo razoável e eficaz. Essa excessiva utilização só favorece os maus pagadores (que conseguem a procrastinação das suas obrigações) e aos litigantes oportunistas (que se aproveitam das brechas da lei para angariar recursos). Em contrapartida, a situação dos trabalhadores honestos se agrava ainda mais, porquanto têm uma Justiça morosa e pouco eficiente (STF, 2018, on line).

Nesse sentido, o Ministro cita "A Tragédia dos Comuns", de Garrett Hardin, como um exemplo de que recursos finitos precisam ser racionalizados, a fim de que não se tenha a ruína total do bem. Logo, "sem conter a sobrecarga gerada para o judiciário, o próprio acesso à justiça é comprometido, pela inexistência de filtros mínimos de controle da quantidade de ações, provocando uma má prestação jurisdicional” (STF, 2018, on line).

No que se refere à arguição de inconstitucionalidade dos artigos 790-B caput e $\S 4^{\circ}$, bem como, 791-A $\S 4^{\circ}$, da Lei $n^{\circ} 13.467 / 17$, o Relator entendeu que as medidas são adequadas (atendendo ao fim que se propõem, a saber: diminuir o contingente de demandas frívolas), razoáveis (porque não representam um gravame em excesso) e proporcionais em sentido estrito (pois visam o uso equilibrado do Poder Judiciário). Entretanto, buscando resguardar as verbas alimentares e o mínimo existencial, sustentou que as cobranças sucumbenciais não podem incidir sobre valores essenciais para a manutenção da dignidade do trabalhador, devendo-se estabelecer critérios limitadores, quais sejam: (i) os valores destinados ao adimplemento dos honorários advocatícios e periciais não podem ultrapassar a 30\% (trinta por cento) do crédito líquido recebido, sendo a parcela restante verba alimentar, e tal percentual fora escolhido por ser comumente utilizado nos casos de empréstimo bancário; (ii) somente poderá ser descontado, em outro processo, os créditos que excederem o limite do Regime 
Geral da Previdência Social, que atualmente é de R \$ 5.645,89 (cinco mil seiscentos e quarenta e cinco e oitenta e nove centavos), e o valor apontado mostra-se razoável, visto que é considerado suficiente para manutenção da dignidade da pessoa aposentada ou pensionista. Caso seja menor o crédito alimentar a ser percebido pelo reclamante, este estará dispensado do pagamento das custas e honorários processuais (STF, 2018, on line).

Por fim, aduziu o Ministro Luís Roberto Barroso que o art. $844 \S 2^{\circ}$, introduzido pela Reforma Trabalhista, revela-se razoável e proporcional, sendo legítima a cobrança de custas judiciais quando o reclamante não comparece à audiência. Contudo, o reclamante deve ser intimado pessoalmente para quitar a aludida despesa, assim, o trabalhador terá o efetivo direito de justificar sua ausência, conformando a referida Lei com a Constituição de 1988 (STF, 2018, on line).

\subsection{Do Ministro Edson Fachin}

O Ministro Edson Fachin proferiu o seu voto sustentando que, entre os obstáculos do acesso à justiça no Brasil, o mais expressivo é a dificuldade de ordem financeira, de modo que os mais pobres são os que menos possuem acesso à justiça institucionalizada. Isso porque os custos processuais são elevados, além de ser escasso o serviço de assistência jurídica gratuita (STF, 2018, on line).

Ressalta o referido Ministro que o direito fundamental de acesso à justiça está resguardo não somente pela Constituição pátria, mas também por normas internacionais, em especial o art. $8^{\circ}$ da Convenção Interamericana de Direitos Humanos (Pacto de São José da Costa Rica $)^{14}$. "Trata-se, indubitavelmente, de garantia fundamental cuja previsão em normas internacionais indica sua dúplice eficácia em nosso ordenamento jurídico-constitucional, a reforçar, de forma contundente, a proteção ao direito fundamental à gratuidade da Justiça" (STF, 2018, on line).

Dessa forma, ainda que, em tese, as alterações trazidas pela Reforma Trabalhista sejam adequadas, necessárias e razoáveis, duvidosa é sua constitucionalidade em concreto, tendo em vista as condições restritivas ao exercício do direito de demandar para o trabalhador, desestimulando aquele que já sofre com outros estigmas. Ademais, mesmo o reclamante que

\footnotetext{
${ }^{14}$ Art. $8^{\circ}$ : Toda pessoa tem direito a ser ouvida, com as devidas garantias e dentro de um prazo razoável, por um juiz ou tribunal competente, independente e imparcial, estabelecido anteriormente por lei, na apuração de qualquer acusação penal formulada contra ela, ou para que se determinem seus direitos ou obrigações de natureza civil, trabalhista, fiscal ou de qualquer outra natureza.
} 
tenha uma causa legítima poderá ter receio de ajuizar uma ação, notadamente por retornar muito pouco do valor efetivamente devido, sujeitando-se a acordos desvantajosos. Nessa esteira, defende o Ministro Fachin que: "É preciso restabelecer a integralidade do direito fundamental de acesso gratuito à Justiça Trabalhista, (...)” (STF, 2018, on line).

Destaca o Ministro Fachin que, nesses casos de restrições legislativas a garantias fundamentais, "o risco de violação em cascata de direitos fundamentais é iminente e real, pois não se está a resguardar apenas o âmbito de proteção desses direitos fundamentais em si, mas de todo um sistema jurídico-constitucional de direitos fundamentais deles dependente" (STF, 2018, on line). Portanto, é imperioso garantir a máxima efetividade da norma constitucional, sob pena de se ter o esvaziamento do preceito fundamental, bem como, das demais regras e direitos assegurados por ele.

Acerca dos dispositivos 790-B $\S 4^{\circ}$ e $791-\mathrm{A} \S 4^{\circ}$, da Lei $\mathrm{n}^{\mathrm{o}} 13.467 / 17$, que autorizam a utilização de créditos provenientes de outras demandas judiciais para quitar custas e honorários sucumbenciais, sustentou o Ministro Fachin que o eventual recebimento de créditos decorrentes de um processo judicial, por si só, não modifica a situação de miserabilidade jurídica do trabalhador. Significa dizer que a existência de créditos judiciais, muito raramente, altera a condição de pobreza em que se encontra o reclamante. Logo, tais créditos não podem ser utilizados coercitivamente para o pagamento das custas e honorários sucumbenciais, como dispõe a nova redação dos artigos da CLT, ora impugnados (STF, 2018, on line).

No que tange ao $\$ 2^{\circ}$ do art. 844 , instituído pela legislação reformista, afirmou o Ministro Fachin que, mesmo o reclamante desidioso (que não comparece à audiência e vê seu processo arquivado), tem direito de ingressar com nova demanda sem pagar as custas processuais, desde que, comprovadamente, ainda se encontre em situação de hipossuficiência econômica. Assim deve ser, pois “(...) a gratuidade da Justiça, especialmente no âmbito da Justiça Laboral, concretiza uma paridade de condições, propiciando às partes em litígio as mesmas possibilidades e chances de atuarem e estarem sujeitas a uma igualdade de situações processuais" (STF, 2018, on line).

Ao concluir o seu voto, o Ministro Edson Fachin adverte que a garantia fundamental do acesso à justiça encontra guarida em elementos basilares da identidade da Constituição brasileira, como aqueles que visam concretizar os fundamentos da República Federativa, quais sejam: a cidadania (art. $1^{\circ}$, III, da CF/88), da dignidade da pessoa humana (art. $1^{\circ}$, III, da 
$\mathrm{CF} / 88$ ), a construção de uma sociedade livre, justa e solidária (art. $3^{\circ}$, I, da CF/88), da erradicação da pobreza e da marginalização, além da redução das desigualdades sociais (art. $3^{\text {o }}$, III, da $\mathrm{CF} / 88$ ); as novas regras trazidas pela Reforma Trabalhista depravam os fundamentos da República, reprimindo os direitos sociais dos trabalhadores. Por conseguinte, "o pedido da presente ação direta de inconstitucionalidade deve ser julgado procedente" (STF, 2018, on line).

Em seguida, o Ministro Luiz Fux requereu a vista antecipada dos autos do processo, a fim amadurecer suas ideias, o que foi deferido pelo Colegiado do STF. Por essa razão, o julgamento da $\mathrm{ADI} \mathrm{n}^{\circ}$ 5.766/DF encontra-se suspenso até a presente data.

\section{CRÍTICA AOS VOTOS PROFERIDOS}

No debate até aqui travado no Supremo Tribunal Federal, a razão está com o Ministro Edson Fachin, de modo que se adota aqui o quanto exposto no voto acima destacado, aduzindo-se o que se segue.

Com efeito, não raro, a tentativa de soluções salomônicas, aparentemente sábias, resulta em graves injustiças.

Assim, descabe colocar a conta da morosidade da Justiça do Trabalho e do consequente excesso de demandas trabalhistas nas costas dos trabalhadores, para daí concluir pela constitucionalidade da Lei em questão, ainda que com aparentes ressalvas.

Em verdade, é fácil perceber que o excesso de demandas trabalhistas ocorre primordialmente por conta dos maus empregadores, que não cumprem suas obrigações trabalhistas; eles podem até ser a minoria, mas o fato é que são muitos, o que gera a necessidade de maior investimento na Justiça do Trabalho.

De outro lado, seria insensatez negar que existam demandas maliciosas por parte de alguns empregados, mas este problema, além de insignificante, deve ser solucionado com sanções por litigância de má-fé, que já estão no ordenamento, e que, apesar disso, a Reforma Trabalhista não se esqueceu de repetir na CLT reformada, nunca negando ou dificultando o acesso à justiça a todos os trabalhadores numa lei geral e abstrata.

Não existe maior complexidade da legislação trabalhista, além do que, normalmente, o empregador tem assessoria jurídica e contábil, de modo que o argumento de que tal fator é determinante do excesso de processos trabalhistas não tem o menor sentido; e, se fosse o caso, 
caberia reformar a legislação trabalhista para esclarecer o que nela - por acaso - está obscuro, nunca eliminar ou reduzir direitos e garantias dos trabalhadores.

Não há dúvida que os recursos são finitos e precisam ser racionalizados, mas esta conta não deve ser paga pela parte mais fraca na relação de trabalho.

$\mathrm{Na}$ realidade, o círculo vicioso está justamente neste ponto. Numa sociedade em que a garantia secundária (o sistema de justiça), como é o caso brasileiro em geral (e a Justiça do Trabalho não foge a esta regra) é ineficiente, os delinquentes e maus devedores se sentem estimulados a não cumprir seus deveres. Dito de outro modo, no particular, como a Justiça do Trabalho é ineficiente, isso faz com que maus empregadores não cumpram suas obrigações (e até aqueles que não tenderiam a não agir assim, a tanto se sentem estimulados), o que gera carga excessiva da Justiça do Trabalho.

Se assim é, sustentar que os artigos 790-B caput e $\S 4^{\circ}$ e $791-\mathrm{A} \S 4^{\circ}$, da Lei $\mathrm{n}^{\circ}$ 13.467/17 são adequados, porque diminuirão o contingente de demandas frívolas, são razoáveis, porque não representam um gravame em excesso, e proporcionais em sentido estrito, pois visam o uso equilibrado do Poder Judiciário, é no fundo, um discurso vazio e protetor do empregador e que retira a devida proteção que o processo do mundo civilizado põe em favor do empregado; é, na prática, um verdadeiro contributo a reprimir demandas justas, pois o trabalhador que tem razão (ele é sempre um litigante ocasional) tende a ter medo de um possível resultado improcedente de sua demanda, preferindo perder o direito que tem, a correr o risco de - ao perder determinada causa - ter que pagar o custo do processo ao Estado, os honorários do seu advogado e os honorários do advogado do empregador (este quase sempre um litigante habitual, que, por isso mesmo, normalmente tem advogados contratados em caráter permanente). Esse mínimo de 30\% (trinta por cento) que o Relator propôs é uma contemporização, supostamente justa, mas, que, no fundo, distrai e não afasta a injustiça que tal posicionamento consagra.

Por outro lado, a ideia de que é razoável, proporcional e legítima a cobrança de custas judiciais quando o reclamante não comparece à audiência $\left(\$ 2^{\circ}\right.$, do art. 844 , da Lei $n^{\circ}$ 13.467/17) também é um discurso vazio. A suposta justiça contida na ressalva de o trabalhador dever ser intimado, pessoalmente, para quitar a aludida despesa, e, por isso, ter o efetivo direito de justificar sua ausência, não é nenhuma concessão, sim uma obviedade, já que o bom senso indica que não poderia ser diferente. 
Em verdade, o dispositivo em questão fere a Constituição, porque nega o acesso à justiça. Esquece-se aqui que o empregado despedido está, em regra, em busca de outro emprego necessitando de dinheiro o mais rapidamente possível para sobreviver. É uma evidente situação de estado de necessidade. Normalmente, quando o empregado se ausenta a audiência, motivos não faltam. Sucede que provar isso nem sempre é fácil, de modo que tal exigência é descabida. Chega a ser desumano exigir tal pagamento como condição para promover outra ação.

O incompreensível de toda essa malvada "Reforma Trabalhista" é que nada do que nela é exigido ao empregado hipossuficiente é exigido ao autor que demanda na justiça comum (o que é certo); e justamente o Congresso brasileiro, passa a exigir tal pagamento àquele que é notoriamente mais fraco numa relação jurídica, como a de trabalho, em clara violação ao princípio da proibição do retrocesso social.

Então, há algo de esquisito neste Brasil de 2018, se o Supremo Tribunal Federal não reverter esta esdrúxula e vergonhosa situação, qual seja: a de que será melhor a opção por um processo do trabalho seguindo as normas do Código de Processo Civil do que os dispositivos da CLT reformada, pois o sistema comum é mais protetor a um hipossuficiente qualquer (inclusive empresas) do que a Justiça Especializada, que supostamente deveria proteger ao empregado comprovadamente necessitado.

\section{CONCLUSÃO}

Este breve ensaio se propôs a despertar acerca da relevância do julgamento da ADI $\mathrm{n}^{\mathrm{o}}$ 5.766/DF para o acesso à Justiça do Trabalho no Brasil, visto que competirá à Suprema Corte decidir, em controle abstrato, pela inconstitucionalidade ou constitucionalidade dos artigos 790-B caput e $\S 4^{\circ}, \S^{\circ}$ do $791-\mathrm{A}$ e $\S 2^{\circ}$ do art. 844, todos da Lei $\mathrm{n}^{\circ} 13.467 / 17$. Essas novas regras da legislação trabalhista trazem restrições ao exercício do direito de demandar do beneficiário da gratuidade de justiça.

Assim, a conclusão que aqui se apresenta é no sentido de que se espera que a referida ADI seja julgada totalmente procedente, pois, do contrário, o ordenamento brasileiro - por ato do Congresso Nacional -, mas com o beneplácito do Supremo Tribunal Federal, passaria, na prática, a negar acesso à justiça aos trabalhadores pobres brasileiros, o que seria profundamente lastimável. 


\section{REFERÊNCIAS}

ALEXY, Robert. Teoria de Los Derechos Fundamentales. Madrid: Centro de Estudios Constitucionales, 1997.

ANTUNES, Ricardo. Os sentidos do trabalho: ensaio sobre a afirmação e a negação do trabalho. São Paulo: Boitempo Editorial, 1999.

Riqueza e miséria do trabalho no Brasil II. 1 ed. São Paulo: Boitempo, 2013.

BRASIL, Lei n. 13.467, de 13 de Julho de 2017. Altera a Consolidação das Leis do Trabalho (CLT), aprovada pelo Decreto-Lei $n^{\circ} 5.452$, de $1^{\circ}$ de maio de 1943, e as Leis $n^{o s}$ 6.019, de 3 de janeiro de 1974, 8.036, de 11 de maio de 1990, e 8.212, de 24 de julho de 1991, a fim de adequar a legislação às novas relações de trabalho. Disponível em: <http://www.planalto.gov.br/ccivil_03/_ato2015-2018/2017/lei/L13467.htm>. Acesso em: 02/08/18.

BRASIL, Decreto-Lei n. 5.452, de $1^{\circ}$ de maio de 1943. Aprova a Consolidação das Leis do Trabalho. Disponível em: <http://www.planalto.gov.br/ccivil_03/decreto-lei/del5452.htm>. Acesso em: 02/08/18.

BRASIL, Supremo Tribunal Federal. ADI5766 - AÇÃO DIRETA DE INCONSTITUCIONALIDADE. Processo instaurado em: 25/08/17 Disponível em: $<$ http://www.stf.jus.br/portal/processo/verProcessoAndamento.asp?numero=5766\&classe=A DI\&origem $=A P \&$ recurso=0\&tipoJulgamento=M>. Acesso em: 02/08/2018.

CAPPELLETTI, Mauro; GARTH, Bryant. Acesso à justiça. Porto Alegre: Sergio Antônio Fabris, 1988.

CASTRO, Antônio Escosteguy. $O$ acesso à Justiça e as alterações trazidas pela Lei 13.467/17: a reforma trabalhista e os seus impactos no processo do trabalho. Disponível em: https://www.sul21.com.br/jornal/restricao-ao-acesso-justica-na-lei-13-46717/. Acesso em 21/01/2018.

CUNHA JÚNIOR, Dirley da. Controle de Constitucionalidade: teoria e prática. 8. ed., Salvador: JusPodivm, 2016.

DELGADO, Mauricio Godinho; DELGADO, Gabriela Neves. A reforma trabalhista no Brasil: com os comentários à Lei no 13.467/2017. São Paulo: LTr, 2017.

DURKHEIM, Émile. Da Divisão do trabalho social / tradução: Eduardo Brandão. 2. ed., São Paulo: Martins Fontes, 1999.

GUSTIN, Miracy Barbosa de Sousa; DIAS, Maria Tereza Fonseca. (Re)pensando a pesquisa jurídica. Belo Horizonte: Editora Del Rey, 2014.

HESSE, Konrad. A Força Normativa da Constituição. Trad. Gilmar Ferreira Mendes. Porto Alegre: Sergio Antonio Fabris Editor, 1991.

LEITE, Carlos Henrique Bezerra. Curso de direito processual do trabalho. 16. ed. São Paulo: Saraiva, 2018.

PASSOS, Joaquim José Calmon de. Revisitando o Direito, o Poder, a Justiça e o Processo. Salvador: Editora Juspodivm, 2012. 
PINTO, José Augusto Rodrigues. Processo Trabalhista de Conhecimento. 7. ed. São Paulo: Ltr, 2005.

RODRIGUEZ, Américo. Princípios do Direito do Trabalho. São Paulo: LTr, 1978.

RODRIGUES, Horácio Wanderlei. Acesso à justiça no direito processual brasileiro. São Paulo: Acadêmica, 1994.

SADEK, Maria Tereza (org.). Acesso à Justiça. São Paulo: Fundação Konrad Adenauer, 2001.

SARLET, Ingo Wolfgang. A eficácia dos direitos fundamentais. Porto Alegre: Livraria do Advogado, 2010.

SILVA, José Afonso da. Curso de Direito Constitucional Positivo. 32. ed. São Paulo: Malheiros Editores, 2008.

SOUZA, Wilson Alves. Acesso à justiça. Salvador: Editora Dois de Julho, 2011.

; SABINO, Pedro Augusto Lopes (Org.). Processo e efetividade dos direitos. 1. ed. Salvador: Dois de Julho, 2017.

Acesso à justiça: conceito, problemas e busca da sua superação. Evocati revista, v. 42, p. 42, 2009.

Acesso à justiça e responsabilidade civil do Estado por sua denegação. 109. ed. Salvador: Editora Dois de Julho, 2016.

. Temas de direito do trabalho, processo do trabalho e direito à saúde: abordagem à luz dos princípios jurídicos e dos direitos fundamentais. Salvador: Dois de Julho, 2015.

TEIXEIRA FILHO, Manoel Antônio. O processo do trabalho e a reforma trabalhista: as alterações introduzidas no processo do trabalho pela Lei n. 13.467/2017. São Paulo: LTr Editora, 2017.

TUCCI; José Rogério Cruz e. Garantias Constitucionais do Processo Civil. São Paulo: Editora Revista dos Tribunais, 1999.

WATANABE, Kazuo. Acesso à justiça e Sociedade Moderna. In: GRINOVER, Ada Pellegrini, DINAMARCO, Cândido Rangel, WATANABE, Kazuo. Participação e processo. São Paulo: Revista dos Tribunais, 1988.

WEBER, Max. A ética protestante e o espírito do capitalismo. Companhia das Letras, São Paulo, 2004.

Economia e sociedade: fundamentos da sociologia compreensiva / tradução: Regis Barbosa e Karen Barbosa, Brasília: Editora Universidade de Brasília, 1999. 